\title{
A new disease of wheat caused by Alternaria triticimaculans in Argentina
}

\author{
A Perelló *, C Cordo, MR Simon \\ Areas de Fitopatologia y Cerealicultura, Facultatd de Ciencias Agrarias y Forestales de la Universidad Nacional de la Plata, \\ Consejo Nacional de Investigaciones Cientificas y Técnicas (CONICET), Comisión de Investigaciones Cientificas de la Provincia \\ de Buenos Aires (C/C), Calle 60 y 118 (1900) La Plata, Buenos Aires, Argentina
}

(Received 20 September 1995; accepted 31 January 1996)

Summary - Late maturity wheat plants (Triticum aestivum L) culivars Trigomax and Buck Poncho growing at the Estación Experimental Agropecuaria J Hirschhorn in Los Hornos (Provincia de Buenos Aires) were severely affected by a previously undescribed disease. The leaves initially showed necrotic, irregular brown/grey spots that progressed to general necrosis and death of the leaf. The pathogen was proposed as a new species: Alternaria triticimaculans Simmons and Perroló in 1994. Disease symptomatology and characteristics of the causal agent on potato dextrose agar are described. Eight wheat cultivars exhibited significant differences in disease severity in the field under natural infection with $A$ triticimaculans. Don Ernesto INTA was the most resistant and Pro INTA Isla Verde the most susceptible. Five greenhouse-grown wheat cultivars were inoculated by spraying young and adult plants with conidia of $A$ triticimaculans. Lesions similar to those observed on naturally infected plants were observed. The fungus was reisolated from all inoculated plants and Koch's postulates were fulfilled. Adult plants were more susceptible to the pathogen than younger ones. Inoculations made on disinfected wheat seeds indicated slightly reduced seedling emergence. This is the first reported ocurrence of $A$ triticimaculans on a cultivated plant.

\section{Alternaria leaf blight / wheat / Triticum aestivum / Alternaria triticimaculans}

Résumen - Une nueva enfermedad del trigo causada por Alternaria triticimaculans en Argentina. Plantas de trigo (Triticum aestivum L) de los cultivares Trigomax 200 y Buck Poncho cultivadas en la Estación Experimental Agropeucuaria J Hirschhorn de Los Hornos (Prov de Buenos Aires), resultaron severamente afectadas por una enfermedad no descripta previamente. Las hojas presentaban manchas necróticas irregulares que coalescieron causando la necrosis general y posteriormente la muerte de algunas de ellas. El agente causal de la enfermedad due aislado de hojas infectadas e identificado como una nueva especie: Alternaria triticimaculns Simmons and Perelló. La sintomatología de la enfermedad y las características de su agente causal se describen en este trabajo. Se evaluó el comportamiento a campo de ocho cultivares de trigo con A triticimaculans, encontrándose diferencias significativas en la severidad de la enfermedad entre cultivares. En inoculaciones artificiales demostraron ser también susceptibles al patógeno los cultivares de trigo Buck Ombú, Buck Bagual y Buck Palenque, desarrolando lesiones similares a las observadas en plantas naturalmente infectadas. El hongo fue reaislado desde las plantas inoculadas dando cumplimiento a los postlados de Koch. Las plantas adultas resultaron más susceptibles al patógeno que las jóvenes. Se observó reducción en el porcentaje de emergencia de plántulas en las semillas infectadas artificialmente. La presente constituye la primeria cita de la ocurrencia de A triticimaculans.

\section{Alternaria triticimaculans / trigo / tizón de la hoja / Triticum}

${ }^{*}$ Correspondence and reprints 
Résumé - Une nouvelle maladie du blé causée par Alternaria triticimaculans en Argentine. Des plantes des cultivars de blé tardifs Trigomax et Buck Poncho, poussant à la Estacion Experimental Agropecuaria J Hirshhorn à Los Hornos (province de Buenos Aires) ont été sévèrement affectées par une maladie jusqu'ici non décrite. Au début, les feuilles manifestent des taches nécrotiques brunes à grises, irrégulières, qui progressent vers une nécrose générale et la mort de la feuille. Le pathogène a été décrit comme une nouvelle espèce : Alternaria triticimaculans Simmons et Perello, en 1994. La symptomatologie et les caractères de l'agent causal sur agar pomme de terre dextrose sont décrites. Huit cultivars de blé manifestèrent des différences significatives de sévérité de la maladie en infestation naturelle au champ par A triticimaculans. Don Ernesto INTA était le plus résistant et Pro INTA Isla Verde le plus sensible. Cinq cultivars cultivés en serre ont été inoculés par pulvérisation de conidies d'A triticimaculans sur des plantes jeunes ou adultes. Des lésions similaires à celles observées sur les plantes infectées naturellement ont été observées. Le champignon fut réisolé de toutes les plantes inoculées et les postulats de Koch ainsi respectés. Les plantes adultes furent plus sensibles que les jeunes. Des inoculations faites sur des graines de blé désinfectées induisent une émergence légèrement diminuée. Ceci est la première occurrence d'A triticimaculans sur une plante cultivée.

nécrose des feuilles par Alternaria / Triticum aestivum = blé / Alternaria triticimaculans

\section{INTRODUCTION}

Late maturity wheat plants of the cultivars Trigomax 200 and Buck Poncho with severe foliar necrosis were found at the Estacion Experimental Agropecuaria J Hirschhorn (Los Hornos, Provincia de Buenos Aires) in the spring of 1992. The disease observed affected the mature plant foliage, especially the basal leaves. A fungus identified as Alternaria was isolated from the infected material. It was found to be a new Alternaria species and was named Alternaria triticimaculans Simmons and Perelló (Simmons, 1994). To date, $A$ triticimaculans has only been found in wheat plants in Argentina; the disease has not been reported from any other part of the world. Additionally, there is no mention of the pathogen parasitism on other hosts. Considering the possible importance of this new disease, the aims of this study were to describe the symptoms on wheat for the first time, to study the behavior of the causal agent on potato dextrose agar (PDA), to verify its effect upon wheat cultivars under controlled conditions, and to attempt to detect the presence of the fungus in wheat seeds from different areas.

\section{MATERIAL AND METHODS}

Infected wheat plants were collected in the Province of Buenos Aires, Argentina, in October 1992; the pathogen was isolated from the diseased leaves presenting typical necrotic symptoms. Small sections of diseased leaves were disinfested in $70 \%$ ethanol and $0.1 \%$ mercuric chloride for $1 \mathrm{~min}$, then rinsed twice in sterile distilled water and placed on $2 \%$ potato dextrose agar (PDA). Petri dishes were maintained at $22{ }^{\circ} \mathrm{C}$. Single conidial isolates were derived by removing conidia from the initial isolation dishes, placing them on the surface of water agar, and later transferring single, germinating conidia to PDA.

Morphobiometrical and cultural studies of the fungus were conducted on single spore colonies grown in Petri dishes containing PDA, cultured at $20 \pm 2{ }^{\circ} \mathrm{C}$, under cool-white fluorescent light supplemented with

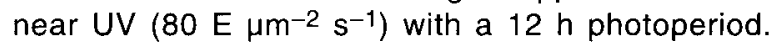
Mycelial color was described according to Rayner's mycological color chart (Rayner, 1970).

Inoculation experiments for studies on pathogenicity were performed in the greenhouse at $15-25^{\circ} \mathrm{C}$ and $85 \%$ relative humidity; photoperiod, $13 \mathrm{~h}$; illumination, $600-1200 \mu \mathrm{E} \mathrm{s}^{-1} \mathrm{~m}^{-2}$ at pot level. The isolate used in the study (designed AT1192) was originally obtained from B Poncho, wheat cultivar in Los Hornos (Prov Buenos Aires, Argentina). Fifteen plants on each of the cultivars Buck Ombú, Buck Palenque and Buck Poncho were grown in three plastic pots $(12 \mathrm{~cm}$ diameter) with a standard potting mix. Plants were inoculated when they had reached the third leaf and heading stage. Inoculum was prepared from 8-day-old cultures of $A$ triticimaculans (isolate AT1192) growing on PDA. Inoculum was obtained by flooding each sporulating PDA plate with $10 \mathrm{~mL}$ of sterile distilled water and gently scraping with a sterile loop. The suspension was filtered once through a single layer of cheesecloth, and spore concentration was determined with a hemacytometer. The inoculum consisted of $1.5 \times 10^{6}$ conidia per milliliter.

Fifteen plants of each cultivar served as non-inoculated controls. Control plants were sprayed with sterile distilled water. For all treatments, both surfaces of the leaves were sprayed to run-off with a manually operated sprayer. The surface of PDA in a Petri dish was sprayed with the spore suspension in order to test for uniformity of spray deposit, the viability of the conidia based on their germination, and contamination. The inoculated plants and controls were kept in a moist chamber for $48 \mathrm{~h}$.

The plants were observed periodically from the third day after inoculation. Reisolation from leaves with lesions was performed and the isolates were compared morphologically with those used for inoculation. 


\section{Seed analysis}

Wheat cultivars Trigomax 200, Trigomax 100 and Buck Bagual seed were used to determine the effect of inoculum on percentage germination. Two hundred seeds per cultivar were disinfested in sodium hypochlorite (5\%) for 15-20 min, rinsed with tap water for $10 \mathrm{~min}$ and submerged for $5 \mathrm{~min}$ in a conidial suspension calibrated to $1 \times 10^{6}$ spore $/ \mathrm{mL}$ by the addition of autoclaved distilled water. Seeds were incubated using the blotter method (ISTA) (Neergaard, 1974). The percentage of seedling emergence was recorded. Disinfected seeds without inoculum were used as controls. Additionally, twenty-five samples of wheat seeds from various ecological wheat areas of Buenos Aires were analyzed by the blotter test to determine if $A$ triticimaculans occurred naturally.

\section{Varietal reaction}

The reaction of eight cultivars of wheat naturally infected with $A$ triticimaculans was tested in the field under natural disease pressure during the 1993 growing season, at Estación Experimental J Hirschhorn, Los Hornos, of the Universidad Nacional de La Plata. The wheat cultivars used are widely grown in the wheat region in Argentina: Cooperación Calquín, Pro INTA Federal, Marcos Juárez INTA, Don Ernesto INTA, Retacón INTA, Pro INTA Isla Verde, Buck Ombú and the hybrid Trigomax 100 (Cargill).

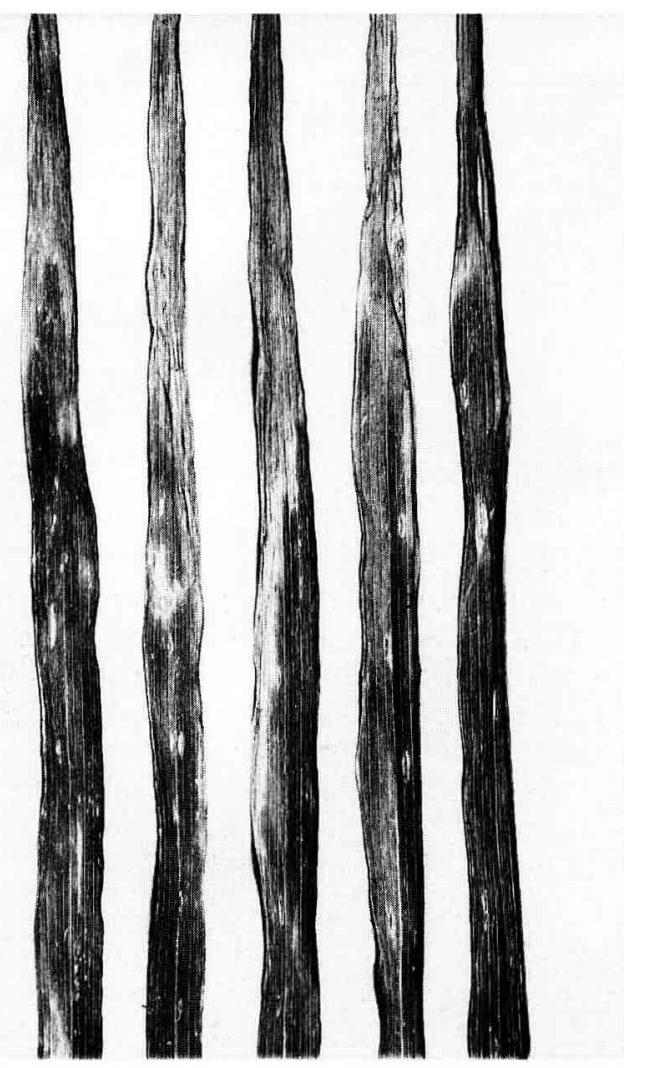

Fig 1. Wheat leaves naturally infected by Alternaria triticimaculans.
The experimental design was a randomized block with three replications: replications were separated by $3 \mathrm{~m}$ of oats to avoid interference. Each experimental unit consisted of a plot of seven rows spaced $20 \mathrm{~cm}$ apart ( $1.40 \mathrm{~m}$ wide $\times 4 \mathrm{~m}$ long). Plots were also separated by $1.40 \mathrm{~m}$ of oat plants. Planting density was 300 plants per $\mathrm{m}^{2}$. Samples were taken from the three central rows of each plot. Evaluations were performed at the soft dough grain stage. The percentage of leaf surface affected by the pathogen in the top three leaves of 20 plants at the soft dough stage (11.2, Feekes scale; Large, 1954), was estimated for each plot.

Data were transformed by the arc sine prior to statistical analysis. Analysis of variance of data was performed for each leaf and for the average of the three leaves assessed.

\section{RESULTS}

\section{Symptomatology}

On the surface of infected leaves from greenhouse-grown plants, small isolated chlorotic lesions $(1.5 \mathrm{~mm}$ in diameter) were first observed. The chlorosis was followed by amphigenous, isolated or confluent, irregular, elliptical or suboval greenish brown spots. A yellow halo was sometimes seen around the lesions. Sometimes the margin of top leaves became brittle when dried and the tissue tore (fig 1). As the disease progressed, lesions developed and spread over the leaf surface resulting in the death of the entire leaf. In natural field infections it was observed that elongated necrotic spots develop progressively from lower to upper leaves. The necrotic tissue becomes covered with mycelium and conidia, either singly or in short chains of two or three.

All wheat plants inoculated with A triticimaculans in the greenhouse developed symptoms identical to those observed on naturally infected plants in the field. Only adult plants became heavily infected. Young seedlings developed either no symptoms or small necrotic spots on some leaves.

The pathogen was isolated and compared with the original isolates to fulfill Koch's postulates.

No symptoms were observed on any control plants.

\section{Description of the fungus}

The fungus develops circular colonies, which have a filamentous margin, a smooth surface and 
an olivaceaous/grey color on PDA (121, Rayner; Rayner, 1970). The mycelium is at first cottonlike, white greyish, then turns into olivaceous buff (108) when submerged. Conidiophores are septate, single, erect, and from 4-6 x 15-30 $\mu \mathrm{m}$ in size. Conidia are produced singly or in short chains of two or three, smooth, irregularly oval, ellipsoid or conical ellipsoid. The light brown spore becomes darker with age with between three and six or seven longitudinal septa. The size varies from $41.25-97.50 \times 11.25-18.75 \mu \mathrm{m}$ (fig 2).

Morphological variability between single conidial isolates was not observed. The dried holotype culture has been deposited in the BPI
Herbarium, US National Fungus Collections (EGS 41-050) (Simmons, 1994).

\section{Seed analysis}

The emergence of artificially inoculated seed of Trigomax 200, Trigomax 100 and B Bagual was 75,80 and $90 \%$ respectively. Infected seeds were totally or partially black (figs 3 and 4 ). The controls germinated with a $100 \%$ success rate and had no blackening of seeds.

None of the samples from producers fields had A triticimaculans.

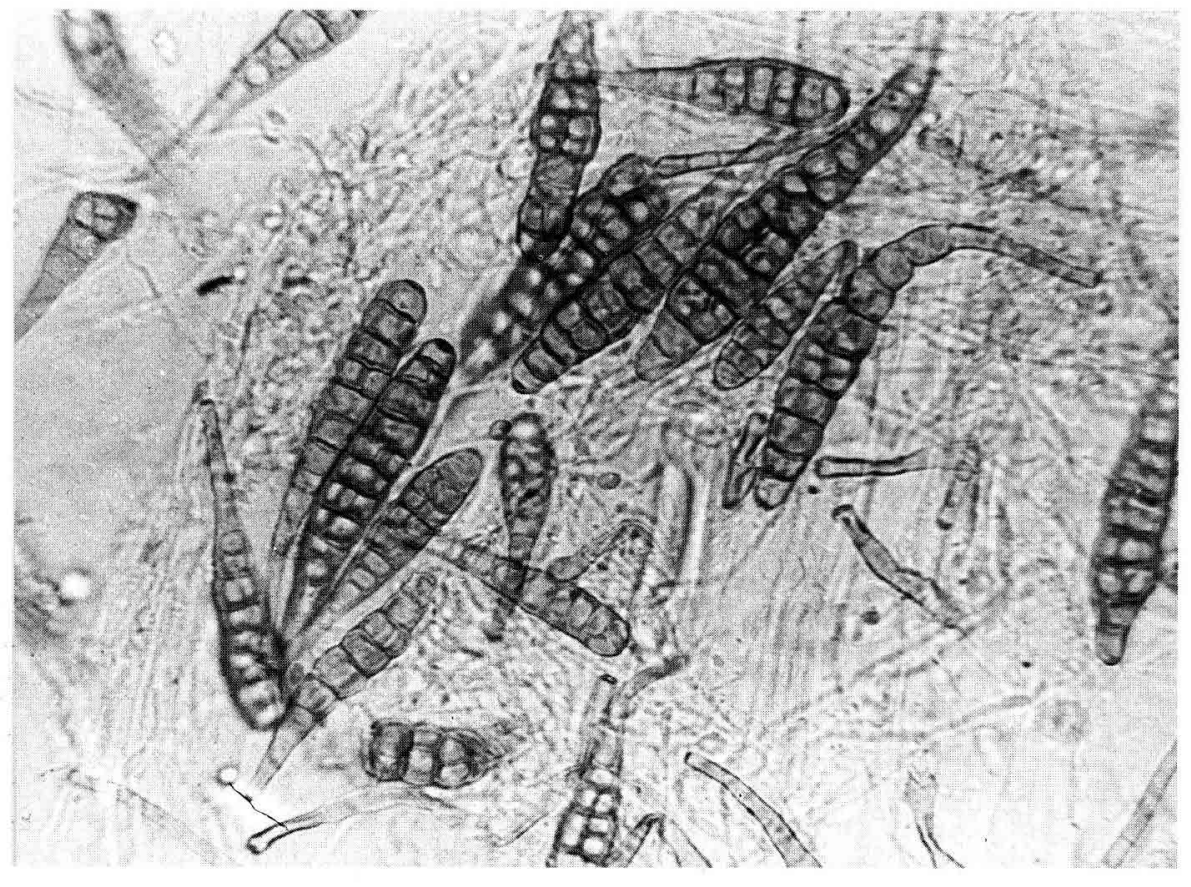

Fig 2. Conidia of Alternaria triticimaculans. Bar represents $20 \mu \mathrm{m}$.

Table I. Reaction of selected wheat cultivars to Alternaria triticimaculans in the field.

\begin{tabular}{|c|c|c|c|c|}
\hline Wheat cultivars & Flag leaf & $2 n d$ leaf & $3 r d$ leaf & Average \\
\hline Don Ernesto INTA & 5.7 y $a^{z}$ & $11.9 \mathrm{a}$ & $33.9 \mathrm{a}$ & $17.17 \mathrm{a}$ \\
\hline Trigomax 100 & $8.5 \mathrm{ab}$ & $19.6 \mathrm{~b}$ & $41.3 a b$ & $23.13 b$ \\
\hline Buck Ombú & $8.5 a b$ & $21.4 \mathrm{bc}$ & $44.4 \mathrm{abc}$ & $24.77 \mathrm{bc}$ \\
\hline Cooperaciọ́n Calquín & $8.7 \mathrm{ab}$ & $22.8 \mathrm{bc}$ & $51.8 \mathrm{bc}$ & $27.76 \mathrm{bc}$ \\
\hline Pro INTA Federal & $8.7 \mathrm{ab}$ & $25.3 \mathrm{bc}$ & $54.6 \mathrm{bc}$ & $29.53 \mathrm{bcd}$ \\
\hline Retacón INTA & $11.0 \mathrm{~b}$ & $28.3 \mathrm{~cd}$ & $54.8 \mathrm{bc}$ & $31.36 \mathrm{cde}$ \\
\hline Marcos Juárez INTA & $16.3 \mathrm{c}$ & $29.6 \mathrm{~cd}$ & $56.5 \mathrm{bc}$ & $34.13 \mathrm{de}$ \\
\hline Pro INTA Isla Verde & $20.2 c$ & $37.2 \mathrm{~d}$ & $57.1 \mathrm{c}$ & $38.17 \mathrm{e}$ \\
\hline
\end{tabular}

$y=$ Percentage leaf area affected by disease at soft dough; average of three replications and 20 leaves per replicate. ${ }^{z}=$ Means followed by the same letter are not different statistically $(P=0.05)$. 

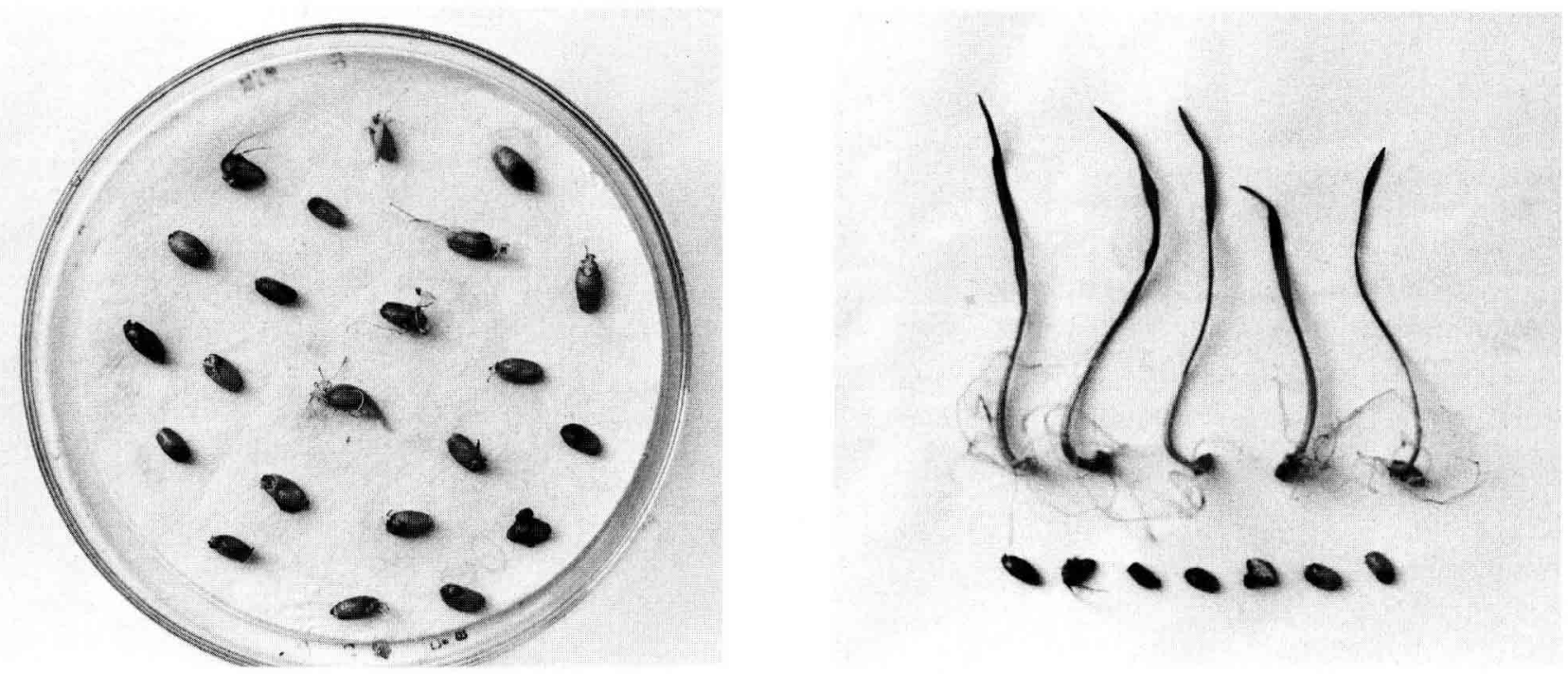

Figs 3 and 4. Wheat seed and seedlings seven days after inoculation with Alternaria triticimaculans.

\section{Varietal reaction}

Disease in the field was observed at the beginning of the flowering stage (10.5, Feekes scale). Lesions expanded rapidly, so that by the milk stage lesions covered a significant percentage of the leaves.

Analysis of variance revealed that there were significant differences in disease severity among the cultivars, both when evaluating individual leaf portions and their average (table 1). Don Ernesto INTA was the most resistant cultivar, and Pro INTA Isla Verde the most susceptible. Pro INTA Isla Verde was similar to Marcos Juárez INTA and Retacón INTA.

\section{DISCUSSION}

Taxonomic relationships of Alternaria spp infecting wheat are discussed in a recent review (Simmons, 1994) where Alternaria origanensis Simmons, $A$ metachromatica Simmons and $A$ triticimaculans Simmons and Perelló are described as spp nov. These three species taxa are discussed in comparison with typical A infectoria, previously described on Triticum sp (Simmons, 1986). Two other very distinctive alternaria species, A triticina (Prasada and Prabhu, 1963) and A triticicola (Rao, 1964), originally described from wheat but considered not to be morphological members of the $A$ infectoria complex, are included by Simmons (Simmons, 1994) for the purposes of contrast and guidance in the identifica- tion of these Triticum inhabitants. In spite of their morphobiometrical and cultural differences, there are similarities in the symptomatology observed under field and greenhouse conditions in the pathogenic behaviour of $A$ triticina and $A$ triticimaculans.

The intensity of infection by $A$ triticimaculans and $A$ triticina is closely related to weather conditions and the vigor and age of the plants; high relative humidity and temperature are favorable for successful infection. A positive correlation between susceptibility and plant maturity was found in A triticina (Prabhu and Prasada, 1966). Adult plants were also the most affected by $A$ triticimaculans. Symptoms develop in the field in the begining of mid-spring, coincident with increased rainfall, relative humidity and moderate to high temperature.

Like A triticina (Bhowmik, 1969; Kumar and Arya, 1973; Neergaard, 1983), A triticimaculans can infect seeds. We observed reduction of emergence of artificially infected seeds, but no necrotic or wilt symptoms were observed in emerged seedlings.

The fact that it has recently appeared on cultivars grown in Argentina shows the importance of a thorough survey by wheat companies in order to investigate the reaction of cultivars to the pathogen. It is supposed that other wheat cultivars, apart from those checked, may also be susceptible to infection by the pathogen. The severity of the foliar symptoms and the reduced emergence of inoculated seeds could have an adverse effect on wheat culture in Argentina and possibly other regions as well. 


\section{REFERENCES}

Bhowmik TP (1969) Alternaria seed infection of wheat. Plant Dis Rept 53, 77-80

Kumar R, Arya H (1973) Certain aspects of perpetuation and recurrence of leaf blight of wheat in Rajasthan. Indian J Mycol Plant Pathol 3, 93-94

Large EC (1954) Growth stages in cereals, illustration of the Feekes scale. Plant Pathol 3, 128-129

Neergaard P (1974) Report of the IV Regional Workshop on Seed Pathology for Developing Countries. Danish Government Institute of Seed Pathology, Copenhagen. $22 \mathrm{p}$

Neergaard P (1983) Seed Pathology Vol 1, Copenhagen, Denmark, $839 p$
Prasada R, Prabhu A (1963) Leaf blight of wheat caused by a new species of Alternaria. Indian Phytopathol 15, 292-293

Prabhu A, Prasda R (1966) Pathological and epidemical studies on leaf blight of wheat caused by Alternaria triticina. Indian Phytopathol 19, 95-112

Rao VG (1964) An undescribed species of Alternaria on wheat from India. Mycopathol Appl 23, 311313

Rayner R (1970) A Mycological Colour Chart. Comm Mycol Inst Key Surrey and British Mycol Soc

Simmons E (1986) Alternaria themes and variations. Mycotaxon 25, 287-308

Simmons E (1994) Alternaria themes and variations. Mycotaxon, 50, 409-427 